SYNTHESIS OF ZSM-5 ZEOLITE USING DIATOMITE AS PRECURSOR; ITS APPLICATION IN THE METHANOL TO HYDROCARBONS PROCESS (MTH)

\section{SÍNTESIS DE ZEOLITA ZSM-5 UTILIZANDO DIATOMITA COMO PRECURSOR; SU APLICACIÓN EN EL PROCESO DE METANOL A HIDROCARBUROS (MTH)}

Received 10152019

Accepted 12252019

Published $1230 \quad 2019$

Vol. 36, No.5, pp. 198-209, Nov./Dic.2019

Revista Boliviana de Química

36(5), 198-209, Nov./Dec. 2019

Bolivian Journal of Chemistry

DOI : $10.34098 / 2078-3949.36 .5 .2$

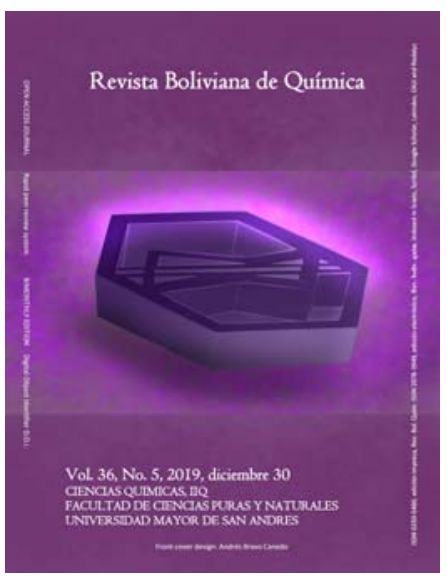

Peer-reviewed

Full original article

Ronald M. Lara Prado ${ }^{1, *}$, Dayana M. Capcha Vargas ${ }^{1}$, Yamil Acho Sarzuri ${ }^{2}$, Edgar Cárdenas $^{1,3}$, Gustavo García ${ }^{1}$, Saúl Cabrera M. ${ }^{1,2}$, Luis López N. ${ }^{1,2}$

${ }^{1}$ Instituto de Investigaciones Químicas IIQ, Área de Ciencia de Materiales, Catálisis y Petroquímica, Facultad de Ciencias Puras y Naturales FCPN, Universidad Mayor de San Andrés UMSA, P.O. Box 303, Calle Andrés Bello s/n-Edificio IIQ, Campus Universitario Cota Cota, Phone +59122795878, La Paz, Bolivia, http://cienciasquimicas.umsa.bo/

2Instituto del Gas Natural IGN, Universidad Mayor de San Andrés UMSA, P.O. Box 303, Calle Andrés Bello s/nEdificio IIQ, Campus Universitario Cota Cota, Phone +59122795878, La Paz, Bolivia

${ }^{3}$ Chemical Technology, Luleå University of Technology, 97187 Luleå, Sweden

Keywords: Methanol to hydrocarbons, Dimethyl ether, Olefins, Diatomite, H-ZSM-5.

Palabras clave: Metanol a hidrocarburos, Éter dimetílico, Olefinas, Diatomita, H-ZSM-5.

\title{
ABSTRACT
}

Zeolite H-ZSM-5 is widely applied in the petrochemical industry, such as the synthetic process of methanol to hydrocarbons (methanol to hydrocarbons MTH). ZSM-5 zeolite is currently obtained through reagents and expensive processes, being available only a few cheaper alternative routes. In the present investigation, zeolite $\mathrm{H}-$ ZSM-5 was obtained from natural diatomite, then characterized, and finally tested in the synthetic MTH process. The natural diatomite was treated with sulfuric acid to perform hydrothermal synthesis with tetrapropyl ammonium hydroxide (TPA-OH). As a result, the H-ZSM-5 zeolite obtained had a Si / Al molar ratio of 23, it exhibited high thermal stability and showed Lowry-Brönsted and Lewis acid sites. The application of this zeolite in the MTH reaction showed a methanol conversion of $88 \%$. The products were: dimethyl ether (DME) in $40 \%$, olefins (mostly ethylene and propylene) in $40 \%$ and others in $20 \%$. The reaction conditions were: $300{ }^{\circ} \mathrm{C}, 1.2 \mathrm{~L}_{\text {metanol }} / \mathrm{g}_{\text {cat }} \mathrm{h}$ at atmospheric pressure $(0.65 \mathrm{bar})$. The selectivity of the products can be modified in such a way that DME can be 
REVISTA BOLIVIANA DE QUÍMICA

ISSN 0250-5460 Rev. Bol. Quim. Paper edition

ISSN 2078-3949 Rev, boliv. quim. Electronic edition

Ronald M. Lara Prado et al. RBQ Vol. 36, No.5, pp. 198-209, 2019

obtained preferentially, up to $>93 \%$, by changing the operating conditions (temperature and space velocity). The use of natural diatomite as a starting material for the preparation of the zeolite H-ZSM-5 represents an attractive route and deserves further investigation for its application and development.

*Corresponding author: ronaldlara49@gmail.com

\section{RESUMEN}

La zeolita H-ZSM-5 es ampliamente aplicada en la industria petroquímica como por ejemplo en el proceso sintético de metanol hasta hidrocarburos (methanol to hydrocarbons MTH). La zeolita ZSM-5 es obtenida a través de reactivos y procesos costosos, existiendo pocas rutas alternativas que sean más económicas. En la presente investigación, zeolita H-ZSM-5 fue obtenida a partir de diatomita natural, seguidamente caracterizada, y finalmente probada en la proceso sintético MTH. La diatomita natural fue tratada con ácido sulfúrico para la realización de la síntesis hidrotermal con hidróxido de tetrapropil amonio (TPA-OH). Como resultado, la zeolita H-ZSM-5 obtenida tuvo una relación molar Si/Al de 23, presentó estabilidad térmica alta y sitios ácidos Lowry-Brönsted y Lewis. La aplicación de esta zeolita en la reacción MTH, presentó una conversión de metanol del $88 \%$. Los productos fueron: dimetil éter (DME) en un $40 \%$, olefinas (mayoritariamente etileno y propileno) en un $40 \%$ y otros en un $20 \%$. Las condiciones de reacción fueron de: $300^{\circ} \mathrm{C}, 1,2 \mathrm{~L}_{\text {metanol }} / \mathrm{g}_{\text {cat }} \mathrm{h}$ a presión atmosférica $(0.65 \mathrm{bar})$. La selectividad de los productos puede ser modificada de tal forma que pueda obtenerse DME de manera preferencial, hasta $>93 \%$, mediante el cambio de las condiciones de operación (temperatura y velocidad espacial). El uso de diatomita natural como material de partida para la preparación de la zeolita H-ZSM-5 representa una ruta atractiva y merece mayor investigación para su aplicación y desarrollo.

\section{INTRODUCTION}

The methanol to hydrocarbons (MTH) process is a good petrochemical option for the production of clean fuels such as gasoline, diesel or dimethyl ether (DME), with similar properties as compared with fuels obtained from crude oil $[1,2]$. Other products obtained from the MTH process are chemicals such as ethylene and propylene, which are precursors highly demanded in the polymer industry [3,4]. In general, the MTH process uses different kind of zeolites being one of the most common the H-ZSM-5 [5,6]. This zeolite is commonly synthesized from sodium silicate, aluminum nitrate and tetra propyl ammonium hydroxide (TPA-OH) as structure directional agents (SDA) under LBASic $\mathrm{pH}$ conditions [7,8]. The use of less expensive raw materials could reduce the overall synthesis cost of H-ZSM-5 zeolite. One alternative for the H-ZSM-5 zeolite synthesis is the use of natural diatomite, where the diatomite is an attractive source of silica and aluminum and it has the advantage of being a more environmentally friendly process [9]. A proper pre-treatment of diatomite not only reduces the amount of impurities such as $\mathrm{Ca}, \mathrm{Fe}$ and $\mathrm{Mg}$ that are usually present in natural diatomites [10], but also it allows to reach a proper $\mathrm{Si} / \mathrm{Al}$ ratio prior zeolite synthesis [11].

In the present work, the preparation of H-ZSM-5 zeolite using natural diatomite treated with sulfuric acid and subsequent hydrothermal synthesis with TPA-OH, was studied. The zeolite was characterized by XRD, TPD, SEM, ICP, TGA-DSC from which a pure ZSM-5 was identified, trace amounts of metals, high thermal stability, strong Lowry-Brönsted and Lewis acid sites and a $\mathrm{Si} / \mathrm{Al}$ molar ratio of 23. This zeolite showed high selectivity toward dimetil ether $(>97 \%)$ and high conversion $(>68 \%)$ in the MTH process.

\section{RESULTS AND DISCUSSION}

\section{Characterization of H-ZSM-5 obtained from diatomite}

\section{Inductively coupled plasma-sector field mass spectrometry (ICP-SFMS)}

The results from ICP-SFMS show that the treatment of diatomite with sulfuric acid considerably reduces the concentration of metallic elements such as $\mathrm{Al}, \mathrm{Ca}, \mathrm{Fe}, \mathrm{K}, \mathrm{Mg}, \mathrm{Na}$, as it is shown in Table 1. Comparing with a previous work [11] where diatomite was treated in a reflux system with hydrochloric acid at $115^{\circ} \mathrm{C}$ for 150 minutes, the reduction of the concentration of $\mathrm{Al}, \mathrm{Na}, \mathrm{K}, \mathrm{Mg}$ and $\mathrm{Na}$ are practically in the same range, with the exception of 
Ronald M. Lara Prado et al. RBQ Vol. 36, No.5, pp. 198-209, 2019

$\mathrm{Ca}$ and $\mathrm{Fe}$. Also the $\mathrm{SiO}_{2} / \mathrm{Al}_{2} \mathrm{O}_{3}$ ratio is in the same range: 44 from hydrochloric acid treatment and 49.4 from sulfuric acid treatment. The $\mathrm{Si} / \mathrm{Al}$ ratio is a very important parameter for the synthesis of zeolites, since the ratio defines its application as selective a catalyst in several petrochemical processes. For example in the MTH process, the zeolite H-ZSM-5 typically has a Si/Al ratio in the range of $3-\infty$ [12]. The H-ZSM-5 zeolite obtained from diatomite has a $\mathrm{Si} / \mathrm{Al}$ ratio equal to 46.3 , see Table 1 .

Table 1. Composition (in mole \%) of diatomite, acid treated diatomite and H-ZSM-5 zeolite by ICP-SFMS

\begin{tabular}{lccc}
\hline Elemental Composition & $\begin{array}{l}\text { Natural } \\
\text { Diatomite, \% }\end{array}$ & $\begin{array}{c}\text { Acid treated } \\
\text { Diatomite, \% }\end{array}$ & H-ZSM-5, \% \\
\hline $\mathrm{Si}\left(\mathrm{SiO}_{2}\right)$ & $59,0(70.8)$ & $93.4(95.9)$ & $91.1(94.8)$ \\
$\mathrm{Al}\left(\mathrm{Al}_{2} \mathrm{O}_{3}\right)$ & $9.8(5.9)$ & $3.8(1.9)$ & $3.9(2.1)$ \\
$\mathrm{Ca}(\mathrm{CaO})$ & $3.7(4.4)$ & $1.0(1.1)$ & $0.8(0.9)$ \\
$\mathrm{Fe}\left(\mathrm{Fe}_{2} \mathrm{O}_{3}\right)$ & $1.3(0.8)$ & $0.1(0.1)$ & $0.1(0.1)$ \\
$\mathrm{K}\left(\mathrm{K}_{2} \mathrm{O}\right)$ & $2.4(1.4)$ & $0.8(0.4)$ & $1.8(0.9)$ \\
$\mathrm{Mg}(\mathrm{MgO})$ & $4.1(4.9)$ & $0.2(0.2)$ & $0.2(0.2)$ \\
$\mathrm{Na}\left(\mathrm{Na}_{2} \mathrm{O}\right)$ & $19.7(11.8)$ & $0.8(0.4)$ & $2.0(1.0)$ \\
$\mathrm{Total}$ & $100.0(100.0)$ & $100.0(100.0)$ & $100.0(100.0)$ \\
$\mathrm{Si} / \mathrm{Al}\left(\mathrm{SiO}_{2} / \mathrm{Al}_{2} \mathrm{O}_{3}\right)$ & $6.0(12.1)$ & $24.7(49.4)$ & $23.4(46.3)$ \\
\hline
\end{tabular}

\section{$X$-ray diffraction $(X R D)$}

a) Sulfuric acid treatment of the natural diatomite

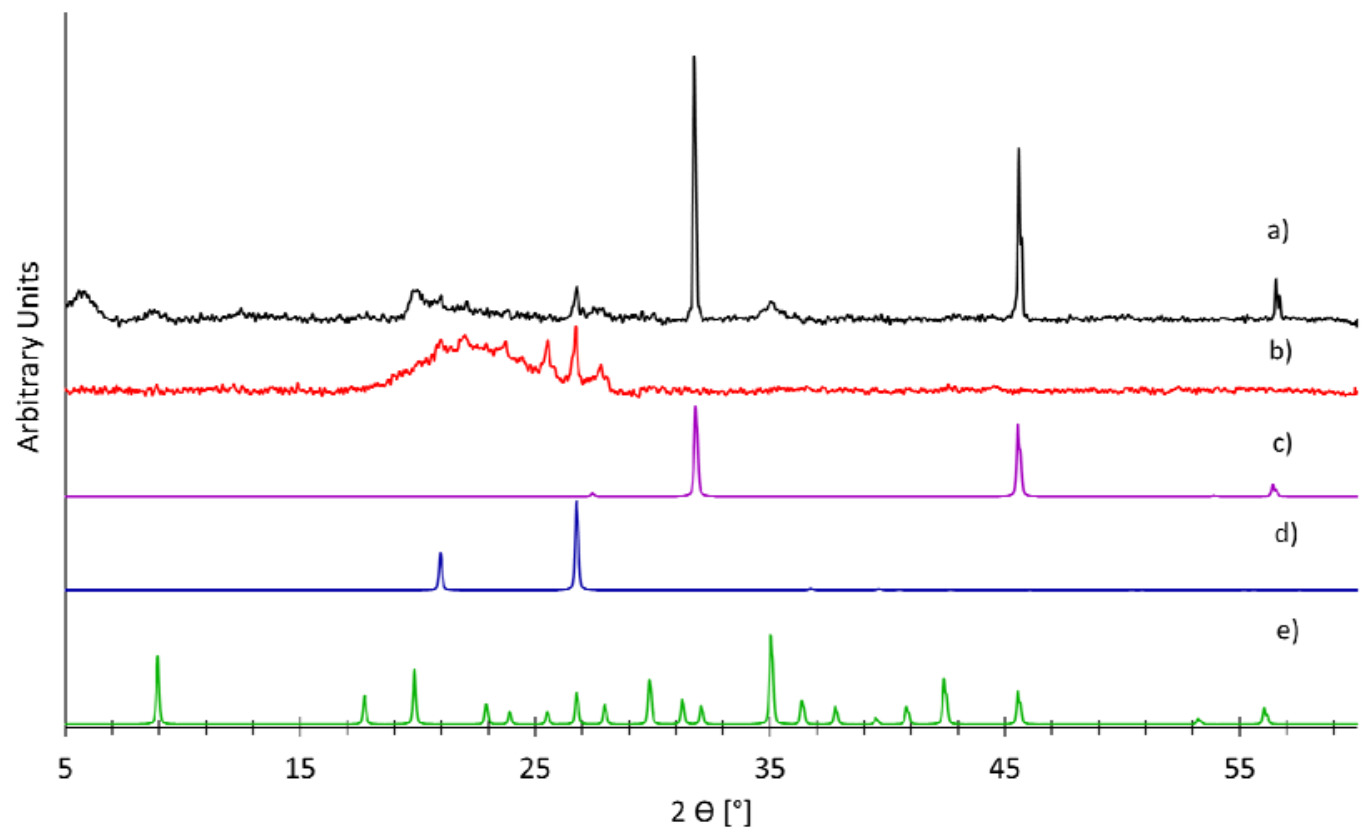

Fig. 1. XRD diffractograms: a) Pure Diatomite, b) Acid treated Diatomite, c) Reference pattern of NaCl Halite (PDF-00001-0993), d) Reference Pattern of $\mathrm{SiO}_{2}$ Quartz (PDF-01-083-2466) and e) Reference pattern of $\mathrm{KAl}_{2}\left(\mathrm{AlSi}_{3} \mathrm{O}_{10}\right)\left(\mathrm{OH}_{2} \mathrm{MusCovite}\right.$ (PDF-00-001-1098)

From the XRD diffractogram of pure diatomite (Fig. 1a) the following structure can be identified: $\mathrm{SiO}_{2}$ as Quartz (Fig. 1d), $\mathrm{NaCl}$ as Halite (Fig. 1c) and $\mathrm{KAl}_{2}\left(\mathrm{AlSi}_{3} \mathrm{O}_{10}\right)(\mathrm{OH})_{2}$ as Muscovite (Fig. 1e). As a consequence of the acid 
Ronald M. Lara Prado et al. RBQ Vol. 36, No.5, pp. 198-209, 2019

treatment of diatomite, the $\mathrm{NaCl}$ and $\mathrm{KAl}_{2}\left(\mathrm{AlSi}_{3} \mathrm{O}_{10}\right)(\mathrm{OH})_{2}$ signals totally disappear while the signals of Quartz are affected in minor degree.

b) Synthesis of H-ZSM-5 from acid treated diatomite

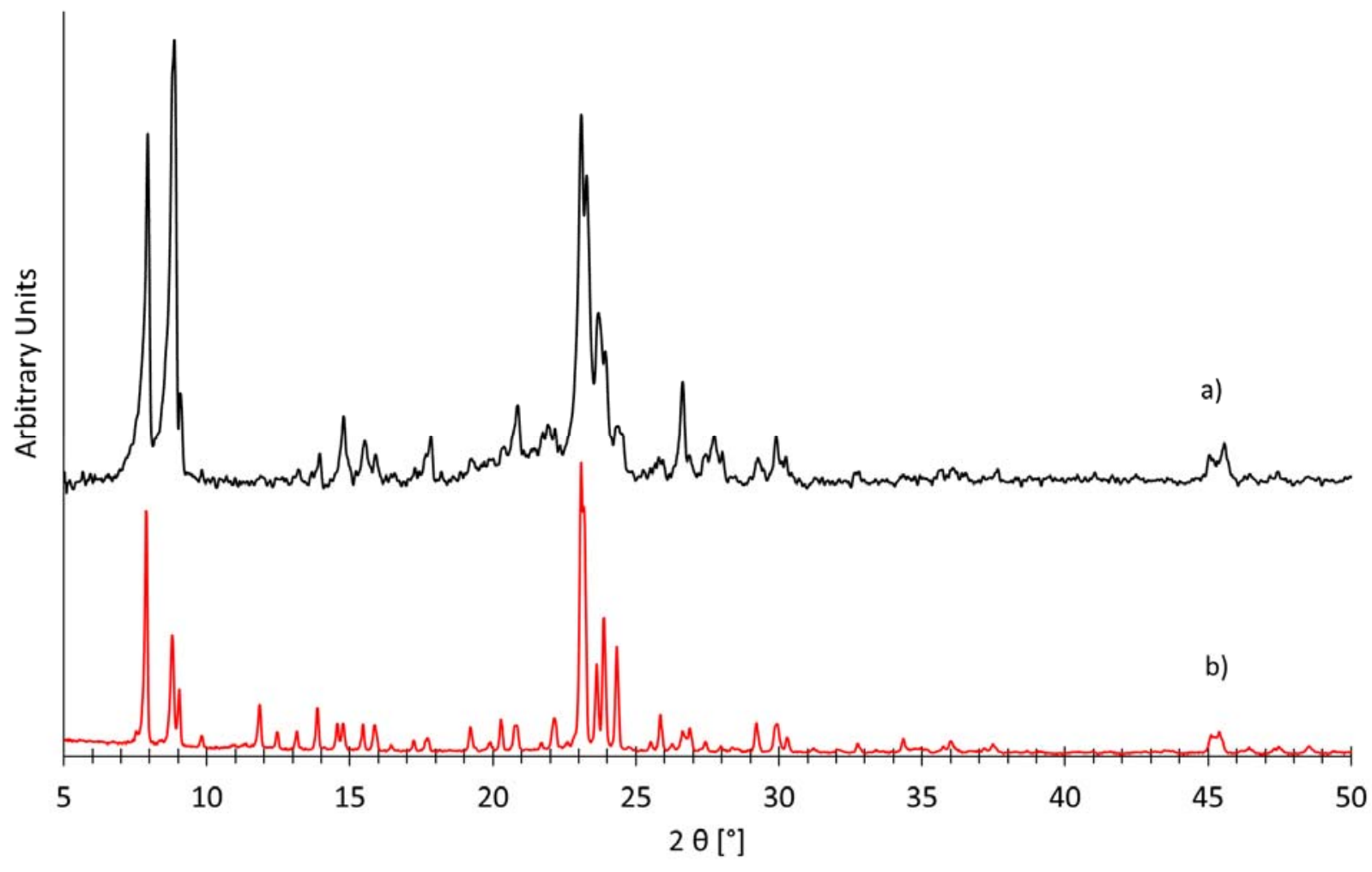

Fig. 2. XRD diffractograms of: a) H-ZSM-5 synthetized from diatomite and b) Reference pattern of H-ZSM-5 zeolite (PDF-0420024)

After a hydrothermal synthesis using the acid treated diatomite and TPA-OH, the H-ZSM-5 zeolite is obtained (Fig. 2a), as identified with the diffraction angles at $2 \theta=7.4^{\circ}$ to $9.2^{\circ}$ and $22.0^{\circ}$ to $25.0^{\circ}$ which correspond to the $\mathrm{H}$ ZSM-5 structure (Fig. 2b). This indicates that the use of diatomite as resource of $\mathrm{Si}$ and $\mathrm{Al}$ is adequate for the synthesis of H-ZSM-5. Moreover, Si and Al from diatomite can form oligomers that could interact in a simpler way with the directional agent TPA-OH, which facilities the synthesis of H-ZSM-5 as suggested in the literature [13]. The crystallinity degree and average crystallite size of the H-ZSM-5 zeolite are $47.0 \%$ and $69,2 \mathrm{~nm}$ respectively.

\section{Scanning electronic microscopy (SEM)}

In the SEM image of the natural diatomite (Fig. 3a) large particles can be observed with the typical shape of diatomite biogenic sediments. The obtained H-ZSM-5 zeolite presents large elongated ellipsoidal particles with sizes between $4.5 \mu \mathrm{m}$ to $10.9 \mu \mathrm{m}$ (Fig. $3 \mathrm{~b}$ ). Moreover, the zeolite particles are formed by agglomerates of nano-crystals as observed in Fig. 3c, which is commonly obtained at high aluminum content [14]. The zeolite nano-crystal size distribution is shown in Fig. 3d where the average particle size is $63 \mathrm{~nm}$, this value is in agreement with the particle calculated from the Scherrer equation equal to $69 \mathrm{~nm}$, (see section 2.1.2).

The DTGA profiles show a high thermal stability up to $800^{\circ} \mathrm{C}$ for all the studied materials; natural diatomite (Fig. 4a), acid treated diatomite (Fig. 4b) and for the final H-ZSM-5 zeolite (Fig 4c). For all the cases a loss of weight is found below $200{ }^{\circ} \mathrm{C}$, which corresponds to the elimination of adsorbed water; $14.9 \mathrm{wt} \%$ in the natural diatomite, $8.8 \mathrm{wt} \%$ in the acid treated diatomite and $3.3 \mathrm{wt} \%$ in the H-ZSM-5. 


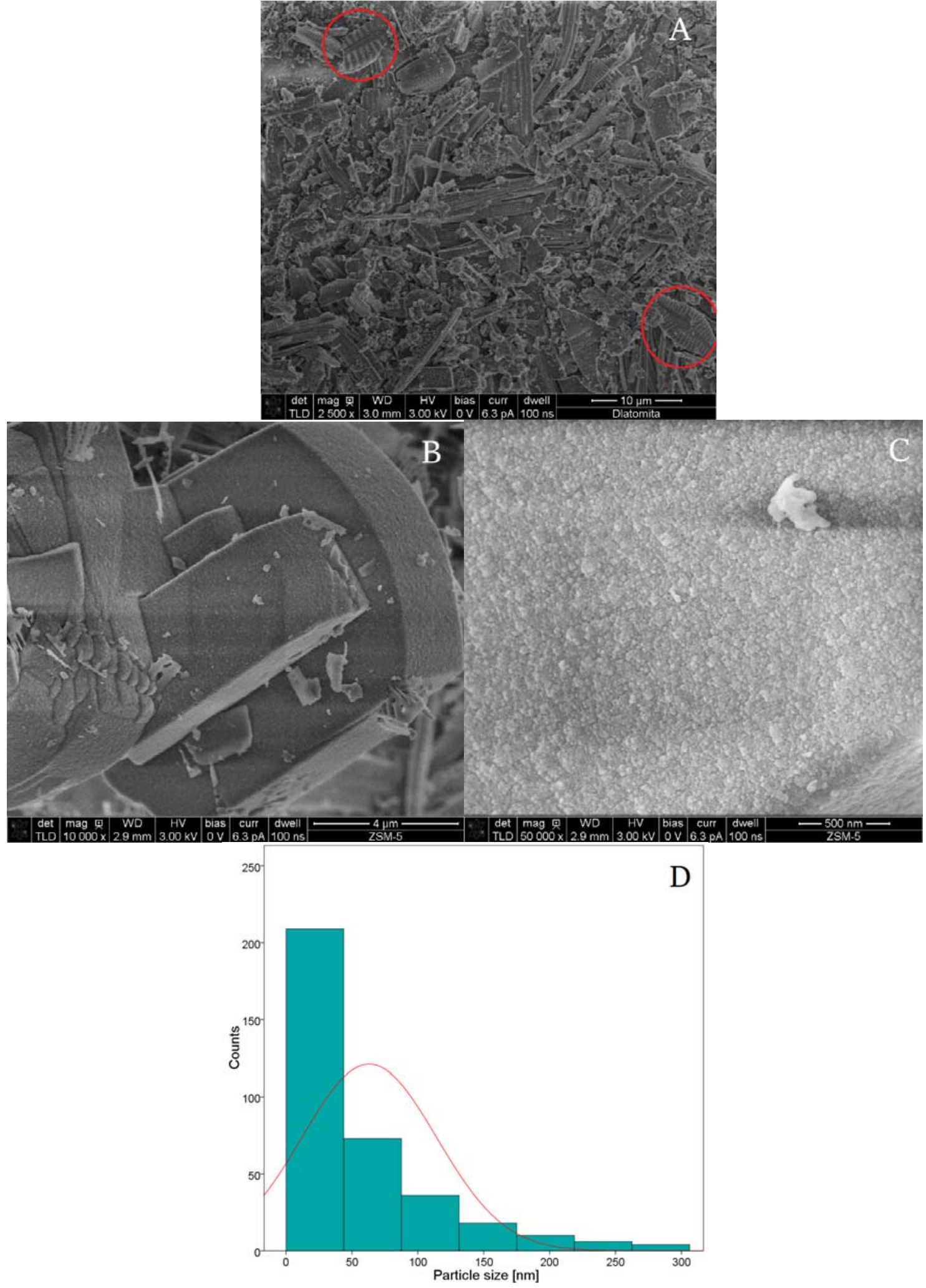

Fig. 3. SEM images of a) Natural Diatomite b, c) obtained H-ZSM-5 zeolite, and d) Zeolite nano-crystal size distribution. Thermal gravimetric analysis (TGA) 


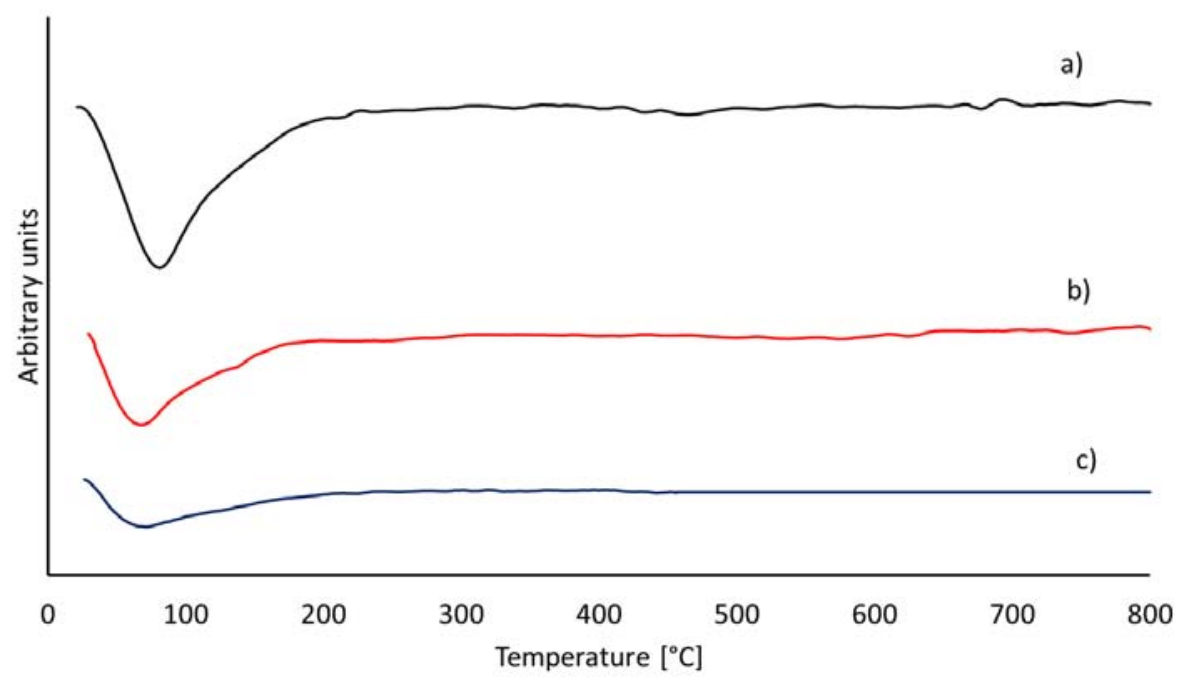

Fig. 4. DTGA profile of: a) Pure Diatomite, b) Acid treated Diatomite and c) obtained H-ZSM-5 zeolite

Ammonia temperature programed desorption $\left(\mathrm{NH}_{3}-\mathrm{TPD}\right)$

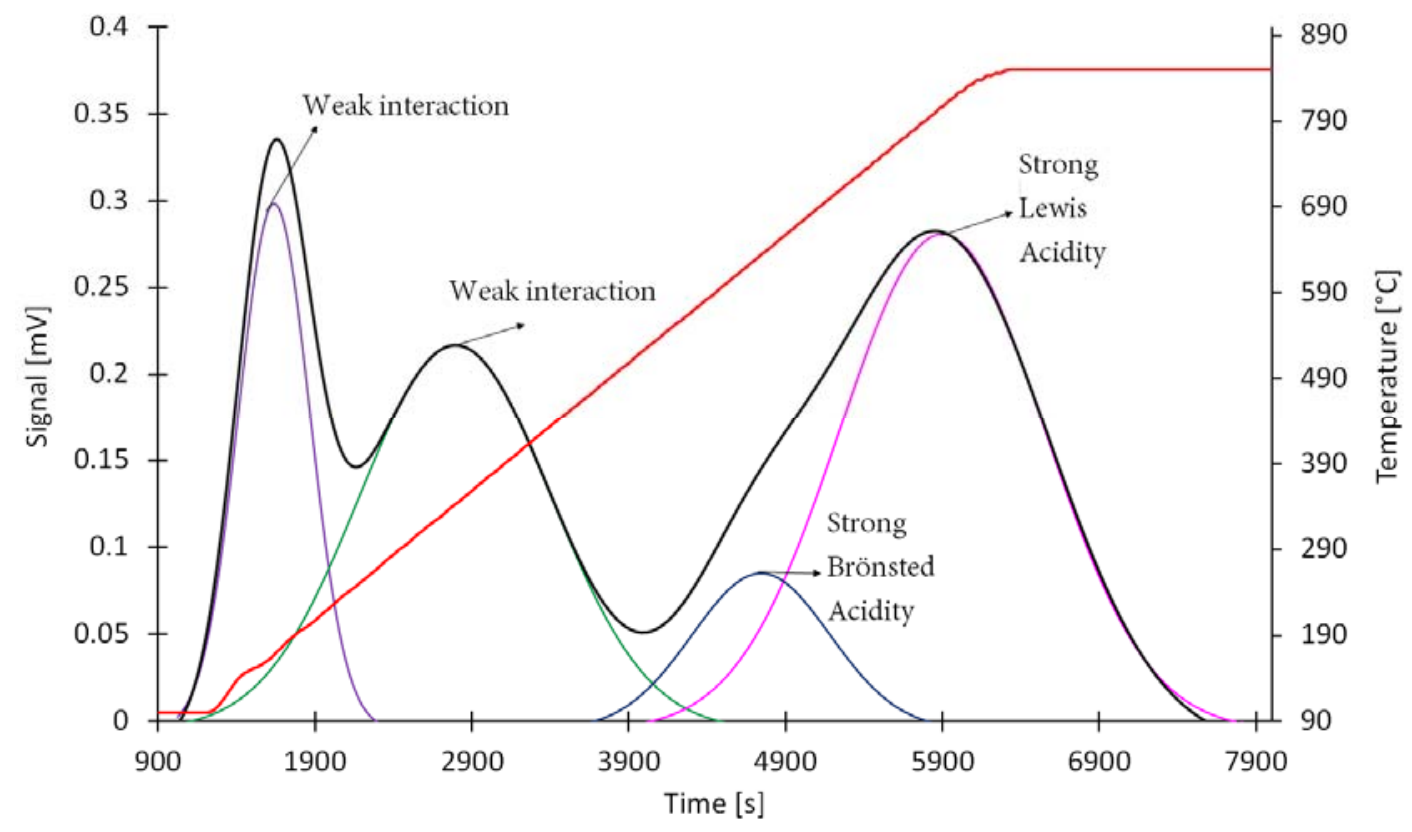

Fig. 5. $\mathrm{NH}_{3}$-TPD profile of the obtained $\mathrm{H}-\mathrm{ZSM}-5$ zeolite

TPD profile of the obtained H-ZSM-5 zeolite show signals in the range of $90{ }^{\circ} \mathrm{C}$ to $850{ }^{\circ} \mathrm{C}$ (Fig. 5), in agreement with the literature for the ZSM-5 zeolite [15-17]. Four deconvoluted signals are assigned in the following range of temperatures; from $100{ }^{\circ} \mathrm{C}$ to $280{ }^{\circ} \mathrm{C}$, from $100{ }^{\circ} \mathrm{C}$ to $550{ }^{\circ} \mathrm{C}$, from $400{ }^{\circ} \mathrm{C}$ to $720{ }^{\circ} \mathrm{C}$, and from $550{ }^{\circ} \mathrm{C}$ to $850{ }^{\circ} \mathrm{C}$. The first and second deconvoluted signals can be assigned to the physically $\mathrm{NH}_{3}$ desorption from $\mathrm{NH}_{4}{ }^{+} \mathrm{nNH}_{3}$ species with $\mathrm{n}=2$ and $\mathrm{n}=1$, respectively, in concordance with the proposed model by Takeuchi et. al. and Lónyi et. al. $[15,18]$. In addition, the second de-convoluted signal can have a contribution of $\mathrm{NH}_{3}$ desorbed from week Lewis acid sites [19-21]. This week Lewis acid site can be originated by $\mathrm{Na}^{+}$which remains in the final ZSM-5 zeolite (see ICP results, Section 2.1.1.).

The third and fourth deconvoluted signals can be assigned to desorption of $\mathrm{NH}_{3}$ from strong acid sites, either a Lowry-Brönsted acid site (LBAS) or a Lewis acid site (LAS) [22]. In order to distinguish between LBAS and LAS, 
an experimental test was carried out where the ZSM-5 was treated with $1 \mathrm{M}$ hydrochloric acid so the extra framework aluminums (EFAL) should preferentially be eliminated and thus the signal of LAS be diminished [2325]. After the $\mathrm{HCl}$ treatment of $\mathrm{H}-\mathrm{ZSM}-5$, about $80 \%$ of the intensity corresponding to the fourth deconvoluted signal was diminished while the intensity of the third deconvoluted signal was diminished only $20 \%$. Thus, we assigned the third deconvoluted signal to LBAS and the fourth deconvoluted signal due to LAS. The LBAS is normally formed by the presence of $\mathrm{H}^{+}$in the zeolite, which at the same time compensate the charge deficiency produced by the intrusion of tetrahedral aluminum into the silicon crystalline structure. [22] While the LAS can be originated by two mechanisms; first, similarly to $\mathrm{H}^{+}$but with a different cation (e.g. $\mathrm{Na}^{+}$and $\mathrm{K}^{+}$), and second, by cationic species such as $[\mathrm{AlO}]^{+}$segregated in the form of EFAL [26-27].

Table 2. Acidity quantification of the H-ZSM-5 zeolite

\begin{tabular}{lccc}
\hline Type of interaction & $\begin{array}{c}\text { Deconvoluted } \\
\text { Signal }\end{array}$ & $\begin{array}{c}\text { Maximum } \\
\text { temperature, }{ }^{\circ} \mathbf{C}\end{array}$ & $\begin{array}{c}\mathbf{M o l e} \\
\mathbf{N H}_{3} / \mathbf{K g}_{\text {zeolite }}\end{array}$ \\
\hline $\mathrm{NH}_{3}$ physisorption (n=2) & I & 175 & 0.15 \\
$\mathrm{NH}_{3}$ physisorption (n=1) & II & 346 & 0.29 \\
Strong Brönsted acid sites (LBAS) & III & 638 & 0.09 \\
Strong Lewis acid sites (LAS) & IV & 808 & 0.40 \\
\hline Total Acidity (LBAS + LAS) & III,IV & - & 0.49 \\
\hline Mole Al/Kg zeolite from ICP $^{*}$ As model proposed by Takeuchi. [18] & & - & 0.57 \\
\hline
\end{tabular}

The quantification of total acidity from TPD, in terms of the amount absorbed of $\mathrm{NH}_{3}$ for the H-ZSM- 5 zeolite was 0.49 mole $\mathrm{NH}_{3} / \mathrm{Kg}_{\text {zeolite, }}$ (see Table 2), which is in agreement with those reported in the literature $[28,29]$. Furthermore, this value is close to the total $\mathrm{Al}$ content in the zeolite; 0.57 mole $\mathrm{Al} / \mathrm{Kg}_{\text {zeolite }}$ found from ICP (see above), suggesting that one $\mathrm{NH}_{3}$ molecule is adsorbed in one acid site which is generated by one aluminum. In addition, some Al species can be trapped into the zeolite's pores being inaccessible for interacting with $\mathrm{NH}_{3}$ molecules.

\section{Catalytic performance of the H-ZSM-5 zeolite in the MTH reaction}

The obtained H-ZSM-5 zeolite was evaluated in the MTH reaction at typical conditions: space velocities (SV) from $\left(1.2 \mathrm{~L} / \mathrm{g}_{\text {cath }}\right.$ to $\left.15 \mathrm{~L} / \mathrm{g}_{\text {cat }}\right)$, temperature from $\left(240^{\circ} \mathrm{C}\right.$ to $\left.300^{\circ} \mathrm{C}\right)$ and atmospheric pressure $(0.65 \mathrm{bar})$. At the beginning of the MTH reaction it was observed an induction period of about 1 hour, where the methanol conversion gradually increased up to a pseudo-stationary state. This period is provoked by the formation and progressive adsorption of intermediary species over the acid sites of the zeolite as described by the hydrocarbon pool mechanism [30-32]. After reaching the pseudo-stationary state, the effect of SV was evaluated in the period A and B and the effect of temperature was evaluated in the period $\mathrm{C}$, as indicated in Table 3.

a) Effect of the space velocity

In period $\mathrm{A}$, the principal products were olefins, mostly ethylene and propylene and DME, and minor amounts of paraffins $\mathrm{C}_{1}$ to $\mathrm{C}_{5}$ and higher $\left(\mathrm{C}_{>5}\right)$, and the methanol conversion was of $88 \%$, close to the equilibrium conversion, namely about $100 \%$. At higher GHSV, period B, the product selectivity changes considerably where the main product becomes DME, superior to $95 \%$ and in minor amounts of olefins, less than $5 \%$, and the methanol conversion decreases in a remarkable diminution until reaching a $54 \%$.

The products obtained in period A can be explained by different reaction mechanisms, one of those is the reaction pathway suggested by Stöcker [30] (see Fig. 6), where the methanol is dehydrated by the capture of a proton from a strong Lowry-Brönsted acid site to form intermediary cationic species, this species remains close for charge compensation. A second molecule of methanol interacts with the cationic species to form DME and regenerate the strong Lowry-Brönsted acid site. DME can react with another cationic species to form light olefins. Then the interaction between light olefins gives larger compounds such as larger olefins and paraffins. At higher GHSV such as the period $\mathrm{B}$ there are minor interactions between reactive species and active sites due to a minor residence time, so, larger compounds are less favored maximizing the selectivity to DME. 
Table 3. MTH results with the obtained H-ZSM-5 zeolite

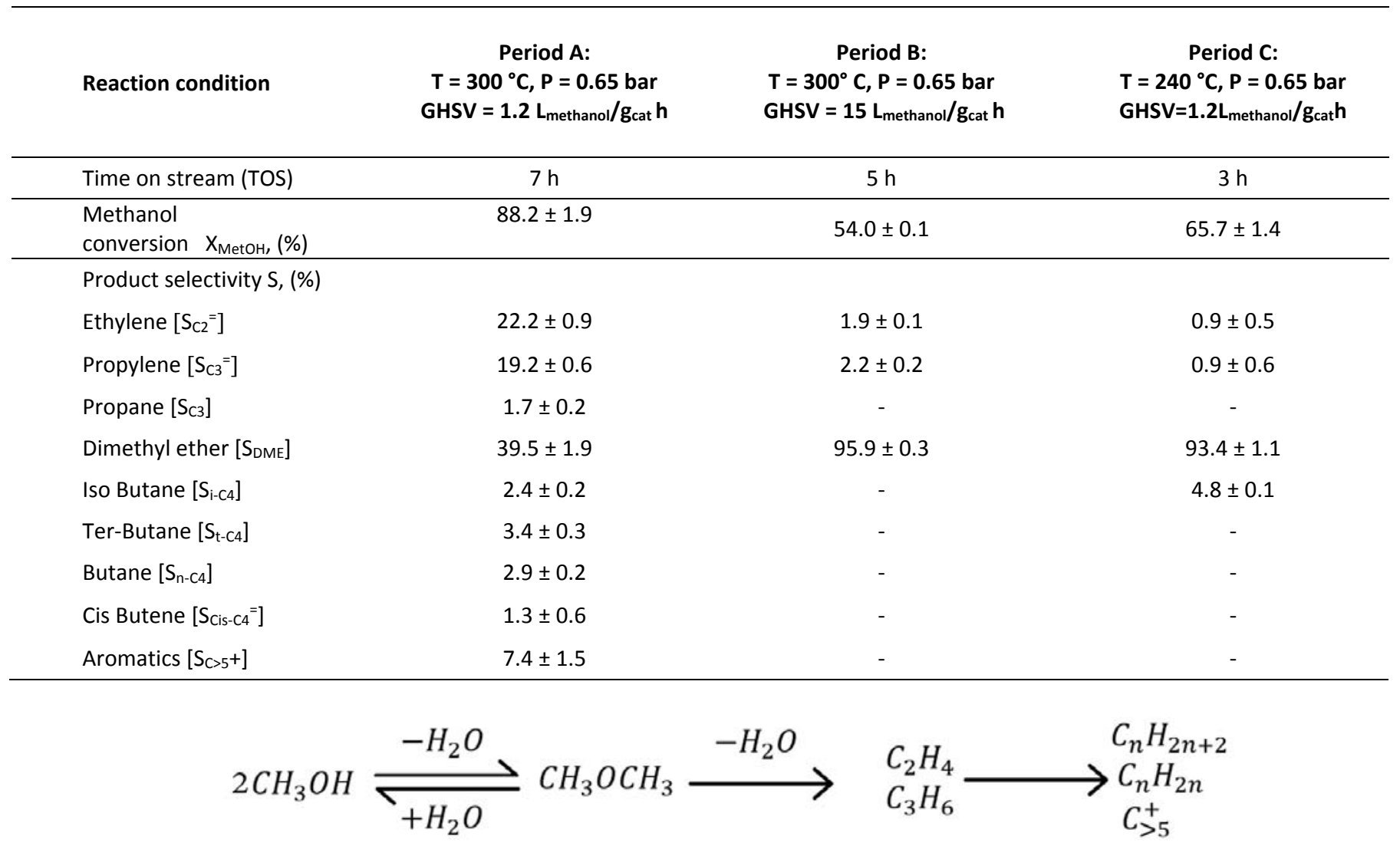

Fig. 6. Reaction pathways for the MTH reaction (adapted from Stöcker [30] Copyright (1999), with permission from Elsevier)

b) Effect of the temperature

After changing the reaction temperature from $300^{\circ} \mathrm{C}$ to $240^{\circ} \mathrm{C}$, the product selectivity is considerably changed, the DME becomes the main product $(>94 \%)$ and minor amounts of olefins and hydrocarbons $(<6 \%)$ are formed (see period $\mathrm{A}$ and $\mathrm{C}$ in table 3 ). The methanol conversion is of $65 \%$ and the equilibrium conversion at this temperature is $100 \%$. Lower temperatures reduce the methanol conversion and changes the product selectivity according to the reported in the literature [33].

\section{EXPERIMENTAL}

\section{Synthesis of H-ZSM-5 zeolite}

\section{Acid treatment of diatomite}

The diatomite used in the present work was collected at the locality of Murmuntani in Potosí, Bolivia at 4067 m.a.s.l. A $6 \mathrm{M}$ solution of sulfuric acid (Merck p.a.) was prepared. The diatomite was treated with the a $6 \mathrm{M}$ sulfuric acid solution under hydrothermal conditions in an oven at $100^{\circ} \mathrm{C}$ during $24 \mathrm{~h}$. Subsequently, the suspension was quenched and washed with distillate water until $\mathrm{pH} \approx 7$. The solid obtained was separated by filtering and dried overnight at $100{ }^{\circ} \mathrm{C}$ 
The synthetic mixture was prepared by using the acid treated diatomite and distillate water, sodium hydroxide (Merck p.a.) and TPA-OH (Merck reactive 1M solution) as SDA. The molar ratios in the synthesis mixture were: $\mathrm{Na}_{2} \mathrm{O} / \mathrm{SiO}_{2}=0.18 ; \mathrm{SiO}_{2} / \mathrm{Al}_{2} \mathrm{O}_{3}=49.4 ; \mathrm{SiO}_{2} / \mathrm{TPA}-\mathrm{OH}=3.5 ; \mathrm{H}_{2} \mathrm{O} / \mathrm{SiO}_{2}=30$, the mixture was stirred for 24 hours at room temperature and the $\mathrm{pH}$ adjusted at 11 with $1 \mathrm{M}$ hydrochloric acid. The mixture was then hydrothermally treated in a Teflon stainless steel autoclave in a pre-heated oven at $170{ }^{\circ} \mathrm{C}$ for 48 hours. Subsequently, the suspension was quenched and washed with distillate water until $\mathrm{pH} \approx 7$. Finally, the obtained solid was dried at 100 ${ }^{\circ} \mathrm{C}$ overnight and calcinated at $550{ }^{\circ} \mathrm{C}$ for 8 hours.

\section{$\mathrm{NH}_{4}{ }^{+}$ion exchange of ZSM-5 zeolite}

The protonated form of the zeolite (H-ZSM-5) was obtained by mixing it with ammonium nitrate $1 \mathrm{M}$ in a reflux system at $80{ }^{\circ} \mathrm{C}$ for 12 hours. The zeolite to ammonium nitrate weight ratio was 1:12. Subsequently, the solid was separated by filtering and washed with distillate water. Finally, the zeolite was dried at $100{ }^{\circ} \mathrm{C}$ overnight and calcinated for 8 hours at $550{ }^{\circ} \mathrm{C}$. This procedure was carried out twice.

\section{Characterization techniques}

The elemental composition of diatomite, acid treated diatomite, and H-ZSM-5 zeolite was quantified with Inductively Coupled Plasma-Sector Field mass spectrometry (ICP-SFMS). $0.1 \mathrm{~g}$ of the sample was fused with $0.4 \mathrm{~g}$ of $\mathrm{LiBO}_{2}$ and dissolved in nitric acid. Each sample was analyzed thrice.

The identification of crystalline phases, crystallinity degree and the average crystal size of the samples was determinated by X-ray diffraction (XRD) technique on a PANalytical X-ray Diffractometer with an X-ray tube of copper $\left(K_{\alpha}=1.54 \mathrm{~A}\right)$ and Xcelerator detector. The operational conditions applied to X-ray tube was $40 \mathrm{~mA} \mathrm{y} 40 \mathrm{kV}$. The analysis range was from $5^{\circ}$ to $60^{\circ}, 2 \Theta$ Bragg degrees.

The crystallinity degree (Eq. 1) [34] was assessed by calculating the area under the principal peaks in the $2 \Theta$ region between $22.0^{\circ}$ to $25.0^{\circ}$ and compared with a high crystalline synthetic zeolite.

\section{\% Grystallntty $=\sum$ Area praks sample/ $\sum$ Area peaks reforence $\quad$ Eq.1.}

The crystallite average size was estimated by using the Scherrer Equation (Eq. 2) where the $\beta$ value was obtained from the highest intense peak.

\section{$\tau=K \lambda / \beta \operatorname{Cos} \theta \quad E q .2$}

The morphology of the samples was studied by scanning electron microscopy (SEM) technique on a SEM Magellan 400, FEI Company, without coating.

The thermal stability was determined by the Thermal Gravimetric Analysis (TGA) technique on a SETARAM TGA-DSC $1600{ }^{\circ} \mathrm{C}$ equipment. The sample was placed in an alumina crucible. The analysis was carried out from 25 ${ }^{\circ} \mathrm{C}$ to $800{ }^{\circ} \mathrm{C}$, heating rate of $10{ }^{\circ} \mathrm{C} / \mathrm{min}$ and $\mathrm{He}$ as carrier gas $(15 \mathrm{~mL} / \mathrm{min})$. The data obtained were converted to derivate form of the TGA (DTGA) using the software of the equipment.

The quantification of the acid sites was carried out by the Ammonia Temperature Programmed Desorption $\left(\mathrm{NH}_{3}\right.$-TPD) technique on a ChemBET TPR/TPD Quantachrom Analysis equipment. A known weight of zeolite was placed in the analysis cell. Then the zeolite was degassed at $250^{\circ} \mathrm{C}$ for $30 \mathrm{~min}$ and activated at $550{ }^{\circ} \mathrm{C}$ for $1 \mathrm{~h}$ with $\mathrm{He}$ as carrier $(15 \mathrm{~mL} / \mathrm{min})$. Subsequently, a flow of $15 \mathrm{~mL} / \mathrm{min}\left(5 \% \mathrm{NH}_{3} / \mathrm{He}\right)$ passed through the cell and ammonia adsorption was carried out for 1 hour at $100{ }^{\circ} \mathrm{C}$. Finally, the gas flow was changed to $\mathrm{He}(15 \mathrm{~mL} / \mathrm{min})$ and heated to $850{ }^{\circ} \mathrm{C}$ at $9{ }^{\circ} \mathrm{C} / \mathrm{min}$. The signals were registered with a TCD detector. For the proper identification of the LowryBrönsted acid sites, a $1 \mathrm{M} \mathrm{HCl}$ solution (1:3 molar ratio) was applied with the ZSM-5 at room temperature for 3 hours. This treatment was performed to eliminate preferentially the extra framework aluminum species (EFAL).

\section{Catalyst performance in the MTH process}

Downloadable from: Revista Boliviana 206 de Química. Volumen 36 №5. Año 2019

http://www.bolivianchemistryjournal.org, http://www.scribd.com/bolivianjournalofchemistry 
ISSN 2078-3949 Rev boliv, quim. Electronic edition

Ronald M. Lara Prado et al. RBQ Vol. 36, No.5, pp. 198-209, 2019

The experiments were carried out in a stainless-steel fixed bed reactor at laboratory scale (see Figure 7), connected to an on-line Gas Chromatograph (Agilent 7890A series and a HP-PLOT-q column) with FID detector. The internal diameter of the reactor was $9.5 \mathrm{~mm}$, in which about $650 \mathrm{mg}$ of catalyst was charged. The catalyst was first activated at $500{ }^{\circ} \mathrm{C}$ with $\mathrm{N}_{2}$ as carrier gas at $20 \mathrm{~mL} / \mathrm{min}$ for 1 hour. Subsequently, the reactor was cooled down to $300{ }^{\circ} \mathrm{C}$. Three different reaction conditions were studied: Condition $\mathrm{A}\left(300^{\circ} \mathrm{C}\right.$ and $1.2 \mathrm{~L}$ methanol $\left./ \mathrm{g}_{\text {cat }}\right)$, condition $\mathrm{B}\left(300{ }^{\circ} \mathrm{C}\right.$ and $\left.15 \mathrm{~L}_{\text {methanol }} / \mathrm{g}_{\text {cat }}\right)$ and condition $\mathrm{C}\left(240{ }^{\circ} \mathrm{C}\right.$ and $\left.1.2 \mathrm{~L}_{\text {methanol }} / \mathrm{g}_{\text {cat }}\right)$. All the experiments were done at atmospheric pressure ( $~ 0.65$ bar). Methanol was injected with a HPLC pump and external heated by heating tape, and mixed with $\mathrm{N}_{2}(20 \mathrm{~mL} / \mathrm{min})$ prior sent to the reactor. HPLC grade methanol was used.

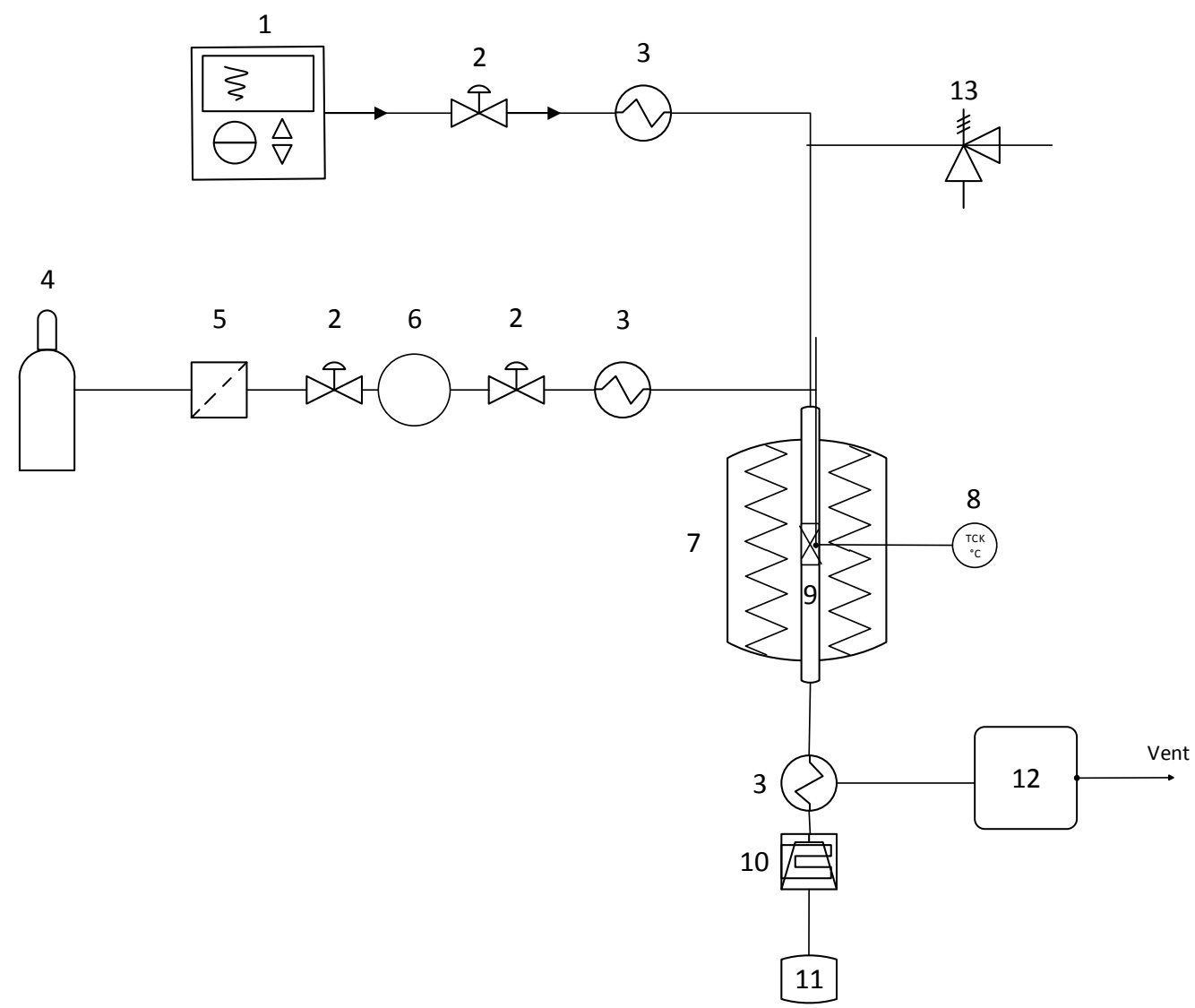

Fig. 7. Schematic overview of the fixed bed reactor. 1) HPLC pump, 2) Simple pass valve, 3) Heating cord, 4) Nitrogen gas cylinder, 5) Filter, 6) Mass flow controller (MFC), 7) Reactor furnace, 8) K type thermocouple, 9) Catalytic bed, 10) Condensation system, 11) Liquids trap and 12) Gas chromatograph.

Methanol conversion was calculated from the following equation [35]:

$$
X=\left(F_{n n}-F_{Q w}^{n}\right) / F_{7 n}^{m} \quad E q^{\prime} g
$$

Where $F_{\text {in }}$ and $\mathrm{F}_{\text {out }}$ refers to molar flow of methanol at feed stream and after reaction, respectively. Product selectivity was calculated from the following equation [15]:

$$
s_{i}=\left(A_{i} / R f_{i}\right):\left(1 / \sum\left(A_{i} / R f_{i}\right)\right) \cdot 100 E q, 4
$$


Where $A_{i}$ refers to the total area of the product " $i$ " and $\mathrm{Rf}_{\mathrm{i}}$ refers to the response factor for product " $\mathrm{i}$ " relative to methane. Some of the response factors were taken from Dietz et. al. [36].

\section{CONCLUSIONS}

The acid treatment of diatomite with sulfuric acid reduces the concentration of elements such as $\mathrm{Na}, \mathrm{K}, \mathrm{Ca}, \mathrm{Mg}, \mathrm{Fe}$ and $\mathrm{Al}$, transforming the diatomite into a good precursor for the synthesis of H-ZSM-5 zeolite. The obtained HZSM-5 zeolite shows high thermal stability, medium crystallinity degree and strong Lowry-Brönsted and Lewis acid sites. From a green chemistry perspective, the acid treatment of diatomite is extremely attractive as an opportunity for the zeolite manufacturing in industry, since it utilizes a natural raw material and would potentially be less expensive compared to traditional synthesis.

The use of the obtained H-ZSM-5 zeolite in the MTH process has showed good methanol conversion ( $>88 \%)$ and high product selectivity of DME and olefins (mostly $C_{2}^{\overline{ }}$ and $C_{3}^{\overline{ }}$ ). By varying the reaction conditions (temperature and space velocity) the DME selectivity can be increased to as high as $95 \%$.

\section{ACKNOWLEDGMENTS}

The authors acknowledge the financial support from The World Academy of Science (TWAS) and Swedish International Development Cooperation (SIDA). Ing. Mario Blanco is acknowledged for providing diatomite samples and facilitate the use of XRD equipment.

\section{REFERENCES}

1. Arcoumanis, C., Bae, C., Crookes, R., Kinoshita, E. 2008, Fuel 87, 1014-1030.

2. Avidan, A.A. 1988, Methane Conversion, 307-323.

3. Sémeril, D., Dixneuf, P.H., Imamoglu, Y., Bencze, L. 2003, Novel Metathesis Chemistry: Well-Defined Initiator Systems for Specialty Chemical Synthesis, Tailored Polymers and Advanced Material Applications 313-322.

4. Al-Megren, H., Xiao, T. Petrochemical Catalyst Materials, Processes, and Emerging Technologies, IGI Global, Engineering Science Reference, 2016, Hershey, PA, USA, pp. 92-115.

5. Seo, G., Kim, J., Jang Catal, H. 2013, Surv. Asia, 17, 103-118.

6. Lefevere, J., Mullens, S., Meynen, V., Van Noyen, J., 2014, Chemical Papers, 68 (9), 1143-1153.

7. Narayanan, S., Sultana, A., Krishna, K. 1995, Catalysis Letters, 34, 129-138.

8. Quan, Y., Li, S., Wang, S., Li, Z., Dong, M., Qin, Z., Chen, G., Wei, Z., Fan, W., Wang, J. 2017, ACS Appl. Mater. Interfaces, 17 (9), 14899-14910.

9. Li, T., Liu, H., Fan, Y., Yuan, P., Shi, G., Bic, X.T., Bao, X., 2012, Green Chem., 14, 3255-3259.

10. Sanhueza, V., Kelm, U., Cid, R., López-Escobar, L. 2004, J. Chem. Technol Biotechnol., 79, 686-690.

11. Aguilar-Mamani, W., García, G., Hedlund, J., Mouzon, J. 2014, SpringerPlus, 3, 292.

12. Xu, R., Pang, W., Yu, J., Huo, Q., Chen, J. Chemistry of Zeolites and Related Porous Materials: Synthesis and Structure, John Wiley \& Sons, 2007, Singapore, pp. 41-72.

13. Pavlova, A., Trinh, T.T., Van Santen, R.A., Meijer E.J. 2013, Phys. Chem. Chem. Phys., 15, 1123-1129.

14. Narayanan, S., Sultana, A., Thinh Le, Q., Auroux, A. 2009, Catalysis Today, 142, 90-97

15. Lónyi, F., Valyon, J. 2001, Microporous and Mesoporous materials, 47, 293-301.

16. Hunger, B., Hoffmann, J., Heitzsch, O., Hunger, M. 1990, Journal of Thermal Analysis, 36, 1379-1391.

17. Nováková, J., Kubelková, D., Habersberger, K., Dolejsek, Z. 1984, J. Chem. Soc., Faraday Trans. I, 80, $1457-1465$.

18. Takeuchi, M., Tsukamoto, T., Kondo, A., Matsuoka, M. 2015, Catal. Sci. Technol., 5, 4587-4593.

19. Lu, C., Liu, T., Shi, Q., Li, Q., Xin, Y., Zheng, L., Zhang, Z. Scientific Reports, published online, 7, 3300.

20. Huang, M., Kaliaguine, S., Auroux. A. Zeolites: A Refined Tool for Designing Catalytic Sites, 97, Elsevier, 1995, Amsterdam, pp. 311-318.

21. Bernardon, C., Osman, M.B., Laugel, G., Louis, B., Pale, P. 2016, Comptes Rendus Chimie, 1-10.

22. Sandoval-Díaz, L. González-Amaya, J., Trujillo, C. 2015, Microporous and Mesoporous Materials, 215, $229-243$.

23. Wang, Q.L., Giannetto, G., Guisnet, G. 1991, Journal of Catalysis, 130, 471-482.

24. Smieskova, A., Bocan, J., Hudec, P., Zidek, Z. 1994, Zeolites, 14, 553- 556.

25. Horňáček, M., Hudec, P., Nociar, A., Smiešková, A., Jakubík, T. 2010, Chemical Papers, 64 (4), $469-474$

26. Deka, R. CH. 1998, Indian Journal of Chemical Technology, 6, 109-123.

27. Huang, J., Jiang, Y., Marthala, Y.R.R., Thomas, B., Romanova, E., Hunger, M. 2008, J. Phys. Chem. C, 112, 3811-3818.

28. Smail, H.A., Rehan, M., Shareef, K.M., Ramli, Z., Nizami, A., Gardy, J. 2019, Chem. Engineering, 3, 35.

29. Chua, S., Yangb, L., Guoa, X., Donga, L., Chena, X., Lia, Y., Mua, X. 2018, Molecular Catalysis, 445, $240-247$.

30. Stöcker, M. 1999, Microporous and Mesoporous Materials, 29, 3-48.

31. Chen, J., Li, C., Yuan, S., Xu, Y., Wei, Q., Wang, Y., Zhou, J., Wang, M,. Zhang, Y., He, S., Xua, Z. 2014, Sci. Technol., 4, 32683277 . 
ISSN 2078-3949 Rev, boliv. quim. Electronic edition

Ronald M. Lara Prado et al. RBQ Vol. 36, No.5, pp. 198-209, 2019

32. Chang, C.D. 1988, Methane Conversion, 127-143.

33. Castellanos-Beltran, I., Palla, G., Lavoie, J. 2018, Chem. Sci. Eng., 12 (2), 226-238.

34. García Mendoza, J.G., Synthesis of zeolites from Bolivian raw materials for catalysis and detergency applications, licentiate thesis, Luleå University of Technology, Department of Civil, Environmental and Natural Resources Engineering.

35. Andersson, R., Boutonnet, M., Järås, S. 2012, Journal of Chromatography A, 1247, 134- 145.

36. Dietz. W.A. 1966, Response factors for gas chromatographic analysis, Journal of Gas Chromatography. https://www.che.psu.edu/faculty/Rioux/group/group info/references/response factors for_gas chromatographic analyses.pdf, Access date: 19/08/2019. 